\title{
Educational Policies in Brazil: Tensions between Union's Regulation and Autonomy of Sub-National Federative Units
}

\author{
Cacilda Rodrigues Cavalcanti, José de Ribamar Sá Silva \\ Department of Education II, Federal University of Maranhão, Brazil
}

\begin{abstract}
This paper analyzes the Union's (Federal Government's) assistance policy to the sub-national federated units (States and Municipalities), from 2004 to 2014, for the provision of basic education in Brazil. The paper discusses the tensions between the federal government policies for technical and financial support to federated units, and the autonomy of the federated units to formulate and implement their own educational policies. The federal government policies implemented since 2004 includes diverse mechanisms for directing the educational policies of sub-national governments and for reducing inequalities in the educational provision. Such approach ended up affecting the degree of autonomy of the federated units and, therefore, tension was created between the two policies. The investigation showed that, although the new assistance policy promoted an increase in the amount of resources transferred to the Northern and Northeastern regions of Brazil, it was not enough to modify the inequality condition. Important discovery of needs for additional research includes the identification of the root causes of, one, the limited management capabilities of Municipality personnel to implement the policies and, two, the actual root causes of the inequalities themselves.
\end{abstract}

\section{Introduction}

Since the Brazilian Federal Constitution of 1988, there has been an increasingly intense debate regarding the federative model used in the field of education for delegating responsibilities and availability of financing for basic education. In the 1990s, the debate focused on decentralization and fiscal adjustments. From the 2000s onwards, the debate shifted to the issues of equity, quality and collaboration in the model.

These new foci lead to a complexity of arrangements in the financing of basic education, in view of the necessary balance between the division of responsibilities, and the availability and parceling of financial resources among the Federal Government, the States and the Municipalities. The current Brazilian Constitution establishes that the responsibilities for education are to be shared by the Federal Government, the States and the Municipalities.

The Federal Government is responsible exclusively for legislating the directives, evaluating the performance, and providing the technical and financial assistance to States and Municipalities regarding national education. In terms of assistance, the Federal Government is responsible for equalizing educational opportunities for all and achieving a minimum standard of quality in the national education. The Federal Government also has the common and concurrent responsibility with the States and Municipalities for the financing and maintenance of the educational systems.

The States have the exclusive responsibility for legislating the directives and for maintaining High School education. Additionally, the States have the concurrent responsibility with the Municipalities for legislating, providing and maintaining Elementary Education. On the other hand, the Municipalities have the exclusive responsibility for providing and maintaining Early Childhood Education.

To guarantee the fulfillment of the responsibilities with public education, the Constitution established a financing model based on the earmarking, redistribution and supplementation of resources transferred to federated units. According to the model, the Federal Government must earmark at least $18 \%$ of its tax revenue for the educational system. At the same time, the States and Municipalities must earmark a minimum $25 \%$ each of their tax revenue for the educational system.

Another source of resources for education comes from the private sector. Accordingly, all firms are required to set aside $2.5 \%$ of their payroll value for the educational system, resources that are viewed as contributions of the private sector to education. Such contributions are known as "salário-educação" or salary-wage, a terminology derived from a previous practice of firms giving scholarships to their workers' children. Resources accrued are distributed equally to the Federal Government, the States and the Municipalities.

However, the existence of this financing model does not guarantee the sufficient level of resources for meeting the responsibilities allocated to the Municipalities. Of particular significance is the fact that many Municipalities are very young and small, and, consequently, do not have tax revenues sufficient for providing the universalization of Elementary Education. Thus, as early as the mid-1990s, the debate intensified in questioning the proposed system of collaboration and requiring a more prominent contribution of the Federal Government to the financing of basic education. This 
paper therefore analyzes the Federal Government's assistance policy to the States and Municipalities, from 2004 to 2014, for the provision of basic education in Brazil. The focus of the analysis is to evaluate whether the new policy implemented since 2004 has contributed to the promotion of equity in the provision of basic education and the tensions between the federal government regulation and the autonomy of subnational governments in the federative dynamics established by this new policy.

\section{Methodology}

The study is based on qualitative and quantitative research (Cavalcanti) [1], combining documentary and statistical analysis. A content analyses was conducted on official documents produced by the National Fund for the Development of Education, FNDE. The FNDE is the Federal Government's agency that regulates and manages the implementation of the technical and financial assistance policies and services.

The documentary analyses investigated 11 Financial Assistance Manuals (one for each year from 2004 to 2014), 11 FNDE Management Reports (one for each year from 2004 to 2014), and 526 normative acts of the financial assistance program (from 1999 to 2014). Frequency distributions of findings were tabulated for each of the documentary sources. The content analysis of the documents was developed according to the model proposed by Bardin [3]. Two grids were developed. One included data on five units of registration, each representing themes of content present in the guidelines of the national policy for basic education. The other included data on fifteen units of registration, each representing themes of content present in the normative acts regulating the federal government's programs of assistance to States and Municipalities.

Descriptive statistics were calculated for the resources transferred to the States and Municipalities, listed in the Transparency Portal of the Federal Government database and the School Census enrollment data reported by the Ministry of Education. The overall transfer values were transformed into per capita value (value/student) using the enrollment data for each year of transfer. Only enrollment data in basic education was considered, excluding professional education enrollment. The amounts were adjusted to present value (of 09/2015) using the IPCA (Índice de Preços ao Consumidor Amplo), an official index based on consumer prices developed by the government to permit comparisons over time. Findings were tabled and graphed.

\section{A conceptual approach to the analysis of federative tensions}

The study about financing of basic education in the Brazilian federation requires a conceptual approach in the theoretical field of federalism. Thus, we seek in the Political Science literature theoretical approaches that support the study of federative tensions and, consequently, make it possible to identify tensions inherent to Brazilian federalism in the field of public education policies.

The conceptual approach of federalism as a structure in permanent tension can be found in the studies of Elazar [2]. This author takes the term federalism as a principle, establishing a conceptual distinction between federalism as a political principle (as theory) and federalism as a structure of division of political power (its application), but advocating an interaction between these two dimensions, so that federal theory can be proved itself empirically, and the practical application of federal rules can be always based on theoretical principles.

In this sense, federalism is conceived by Elazar [2] as the principle of shared sovereignty, whose objective is to reconcile autonomy and interdependence of the constituent units of the federation. This principle therefore leads to a multilevel form of government that combines elements of shared-rule and self-rule, linking individuals, groups and political organizations in lasting but limited union in such a way that as to provide for pursuit of common ends while maintaining the respective integrity of all parties. "Federalism thus defined involves some kind of contractual linkage of a presumably permanent character that (1) provides for power sharing, (2) cuts around the issue of sovereignty, and (3) supplements but does not seek to replace or diminish prior organic ties where they exist" [2].

In the Elazar's [2] approach, the central unity and constituent units of a federative arrangement, through constitutionally defined distribution of power, share decision-making and policy-implementation processes, organized to protect autonomy and interdependence between all governments levels.

Elazar [2] conceives federalism as an alternative to the center-periphery relationship, characteristic model of the unitary state. In Elazar's matrix, integration does not settle around a common center, it is not a force that goes from the center to the peripheries, but both the whole and the parts gain strength simultaneously through a base of interdependence. Different decisionmaking centers are linked through formal lines of authority with both formal and informal lines of communication crisscrossing. The basic principle is the permanently strained integration of unity and diversity, national and local, centralization and decentralization. 
According to Elazar, the necessary combination of diversity and unity creates ambiguities, since federation involves both the creation of unity and the maintenance of the unity and diversity in the form of distribution of power between the levels of government.

The conceptual distinction of federalism and federation of Burgess [4] also moves toward a government system marked by tensions. In contrast to the Reiker's dichotomy about the reasons that lead to the adoption of the federative form, Burgess [4] analyzing the origin and the process of formation of several federations, concluded that ideas, concepts and principles have existed since time immemorial, but it is the circumstances that transform them into experiences, giving them form and meaning.

Burgess [4] argues that a theorizing of federalism cannot abdicate of the historical, structural, institutional and cultural qualities inherent in federalism and all federations. According this understanding, the author proposes a theory of circumstantial causality which, "takes into account a whole host of internal and external factors that have contributed to the creation of federation, taking into account important historical changes and the huge variations that have characterized the origins and formation of different federations" (Burgess) [4]. That is, Burgess [4] introduce the notion of context for an appropriate distinction between federalism and federations.

Burgess [4] considers that a conceptualization of federalism and federation will always face the dilemma of the relationship between flexibility, adaptability and ambiguity. For this reason, the search for a precise definition of federalism together with the possibility of its application in a varied and generalized way, has failed. For the author, federalism must be conceived in its broad sense and in its complexity because it is multidimensional.

The debate on conceptualization of federalism is well summed up by Watts [5]. He points out that in the political theories of federalism the term has been widely used both as a normative idea and as a descriptive category to refer to a certain category of institutions policies. In the author's analysis, this is largely due to an absence of distinction between three terms involved in the analysis of federative systems: federalism, federal political systems, and federations. The term federal political system refers to the broad category of political systems in which, by contrast to a single central source of legal and political authority, as in unitary systems, there are two or more levels of government combining shared-rule and self-rule. These systems range from quasi-federations and federations to confederations. As in a continuum, these categories are not sharply delineated, but are located on one or another margin, as proposed by Riker. Within this broad genus of federal political systems, federations would represent a particular form in which neither the federal unit nor the constituent units of government are constitutionally subordinate to each other; each unit has sovereign power derived from the constitution, not from another level of government.

Based on literature review, Watts [5] lists a set of common structural characteristics of federations as a specific form of federal political systems: a) at least two government orders, one for federation as a whole and another for the regional units, each acting directly on its citizens; b) a formal constitutional distribution of legislative and executive authority and allocation of revenue resources between the two orders of government, ensuring some areas of genuine autonomy for each order; c) representation of distinct regional views within the federal policy-making institutions, usually provided by the particular form of the federal second chamber; d) a supreme written Constitution not unilaterally emendable and requiring the consensus for the amendments of a significant proportion of the constituent units; e) an umpire, in the form of a court, provision for referendums, or an upper house with special powers; f) processes and institutions to facilitate intergovernmental collaboration in those areas where government responsibilities are shared or inevitably overlap.

If a definition of federation is complex due to its diffuse character of operationalization of the federal idea, a conceptual approach to federalism can be useful for understanding the phenomena that are manifested in federations, especially those that derive from the federal structure, such as intergovernmental relationship, the division of competences and resources between the federated units and the degree of centralization and decentralization of policies.

The theoretical approaches of Elazar [2], Burgess [4] and Watts [5] offer significant conceptual contributions to an analysis of federative relations from the perspective of their tensions, since they incorporate political principles and conceive the division of powers structure into a dynamic interaction. The notions of context, complexity, multidimensionality, social diversity and variety of interests present in the theorizing of this authors favor a conception of federative tensions.

Watts [5] operates a set of principles, concepts and fundamental characteristics of federalism and federations for comparative studies. His study focuses on the dynamics that result from the interaction between constitutional form and the operational reality of federative principles, and brings up fundamental issues for the debate on federal political system, which manifest tensions, such as: the form of distribution and allocation of financial resources, the dynamics of relations between national and subnational governments, the degree of centralization and 
decentralization of decision-making authority and financial resources, institutional arrangements for achieving equity, mechanisms and processes government coordination, among others. Watts' analyzes is, therefore, very useful for understanding the tensions intrinsic to the federative form of the Brazilian State in the field of educational policies.

Public policies in the context of Brazilian federalism have been studied by Arretch [6], who in several works has provided support for the analysis of social phenomena that involve tense relations between governments, such as the processes of centralization and decentralization of authority to formulate and implement social policies.

The author suggests a revision of the concepts used to interpret, in a comparative way, the centralization and decentralization of authority. The first fundamental distinction is between the policy-making authority and the policy decision-making authority. The second is about the concepts of political decentralization, fiscal decentralization and executive decentralization, which refer to qualitatively different dimensions of the distribution of authority in national states. Political decentralization refers to the possibility that local governments are directly elected and have an irrevocable mandate for the higher levels of government; fiscal decentralization concerns the participation of subnational governments' revenues and expenditures on aggregate expenditure; and executive decentralization refers to the responsibility for the implementation of public policies. Therefore, for Arretche [7], none of these dimensions taken separately can be interpreted as evidence of a decentralized or centralized federation.

Arretche [7] points out that the federative matrix adopted in the last Brazilian Constitution (1988) combines policy decision-making in the Union and the policy-making in the subnational governments, that is, if, on the one hand, the Constitution adopted the principle of decentralization of the implementation of policies, on the other hand, preserved broad authority for the legislative initiatives of the Union. Such a combination would act positively in the sense of reducing the territorial inequalities that mark the Brazilian federation. The concentration of regulatory authority in the Union creates institutional mechanisms that work to reduce inequalities, while policy implementation by subnational governments operates in the direction of divergence of the policies between jurisdictions. Thus, in the analysis of Arretche [7], the results of public policies cannot be directly deduced from the category of federalism or decentralization. It depends on how these different dimensions combine in sectoral policies. Therefore, it is necessary to observe the institutional arrangements introduced by the constitutional design in each specific policy.
The theoretical approach of the presented authors provides important references for the study of federative relations in the dimension of their tensions, which have their origin in the unavoidable compatibility of autonomy and interdependence established in the division of power and authority among the federated entities. This analytical perspective, through tensions, is possible only by making the conceptual distinction between federalism as a federal principle and federalism as a form, as a specific federal arrangement resulting from the federal principle applied in a specific context, which in the case of this study, is the educational policies in Brazil.

\section{The Federal Government's Assistance Policy for Basic Education from 2004 Onwards}

As indicated previously, the Brazilian Constitution of 1988 and the Law of Basic Directives for National Education (Lei de Diretrizes e Bases da Educação Nacional, law no. 9,394/1996) establishes that the Federal Government is responsible for providing technical and financial assistance to States and Municipalities to guarantee the availability of basic education for all, in such a way as to promote the equity and quality of these services. Such mandate requires that the assistance prioritizes the States and Municipalities with the greatest needs in their educational services.

Federal government assistance up to 2003 was, mainly, carried out through projects developed by the state and municipal governments (called Annual Work Plans), through which these governments demanded financial resources. This form of requirement caused States and Municipalities with greatest capabilities to develop such projects and manage their legal requirements to receive more resources. This situation was changed in 2003 when the Workers' Party (PT, Partido dos Trabalhadores) gained control of the federal government through the election of its candidate to the presidency of the nation. New measures were then established, prioritizing assistance resources to the States and Municipalities with greatest needs.

Evidence shows that until 2003 there were 24 FNDE programs (federally funded assistance programs, i.e., assistance programs funded by the Fundo Nacional de Desenvolvimento da Educação). From 2004 onwards, these 24 programs were reconfigured and 19 new programs were created. In addition, the Federal Government has gradually extinguishing the subnational government's requests for assistance through the Annual Work Plans (that were produced by States and Municipalities), and to develop itself detailed programs outlining assistance services to attend to a myriad of States and Municipalities needs. Besides such 
efforts, the Federal Government also initiated a process of selecting groups of Municipalities that should receive specific assistance in some selected areas.

This new model of assistance peaked in 2007 with the implementation of the Education Development Plan (EDP), which restructured all Federal programs of voluntary transfer under a single policy. This policy articulated the planning and evaluation of State and Municipal systems of education. Two mechanisms were devised to help implement the policy, i.e., the Basic Education Development Index (IDEB), to measure the level of education development of the State and Municipalities, and the Articulated Action Plan (PAR), that should be prepared by states and municipalities as a condition to receive Federal Government technical and financial assistance. Such Plan should be prepared in accordance with the guidelines and model offered by the Ministry of Education, aiming to achieve the goals of the IDEB previously established for a period of four years.

Initially, 1,242 Municipalities with the lowest IDEB were prioritized to receive direct assistance from the Federal Government. Sixteen percent $(16 \%)$ of these were in the Northern region and $67 \%$ in the Northeast. Thus, in total, these two regions had the highest number of Municipalities regarded as prioritary (83\%).

The new assistance policy also redefined the parameters for determining the per capita value that would be transferred to programs. The new guidelines established that the value would be determined on the basis of weights ascribed to region, location (rural or urban), teaching level of program (childhood education, elementary and high school), education modalities (special education, and programs for native Brazilians and Afro-Brazilian descendants) and economic level of tax revenue of the federated unit (the lower the level of tax revenue the greater the need and therefore the greater the weight).

In addition, official documents stated that the principal objective of the new assistance policy was to promote greater equity among the federated entities in order to guarantee more resources to the States and Municipalities with the lowest educational indicators. Thus, the new policy was intended to benefit the States and, especially, the Municipalities in the Northern and Northeastern regions of the country. The next section discusses whether or not the transfer of resources under the new policy met its principal objective.

\section{The Transfer of Federal Resources According to the New Assistance Policy}

The impact of the new policy on the transfer of federal resources to States versus Municipalities was demonstrated in the evolution in the per capita values transferred during the period under investigation (20042014). Two major trends became evident. First, there was an increase in the transfer of resources to programs all over the country. The average per capita value transferred increased from $\mathrm{R} \$ 94.60$ in 2004 to $\mathrm{R} \$$ 262.60 in 2010 (its highest value), an increase of $177.5 \%$.

Second, Municipalities all over the country benefitted more than States for they received, on average, three times more resources. In 2004, the per capita value transferred to Municipalities was only $\mathrm{R} \$$ 13.48. This value increased over time so that in 2014 it reached $\mathrm{R} \$ 105.58$, an increase of $723 \%$ (see Figure 1).

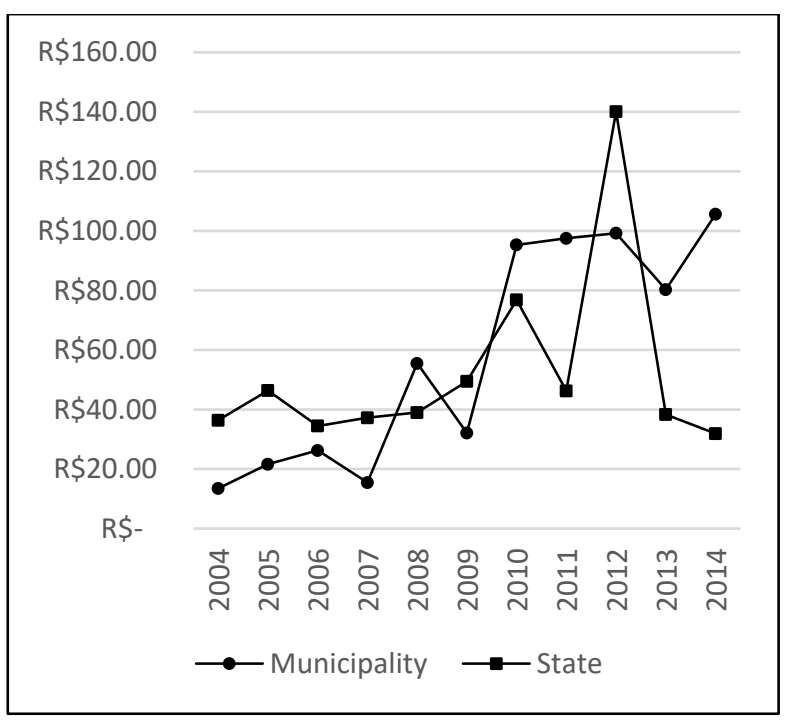

Figure 1. Evolution of federal government transfers of per capita values to states and municipalities, 2004 to 2014

It should be noted that in 2008 there was a significant increase in the transfer of resources to Municipalities, followed by a drop in 2009 and a return to growth from 2010 onwards. Such changes may be associated with, one, the PDE/PAR policy which prioritized in 2008 transfers to 1,242 Municipalities and two, an increase in the transfer of resources from childhood education programs between 2010 and 2012, whose enrollment belongs to municipalities.

On the other hand, the per capita value transferred to States in 2004 was R\$36.40, more than double the per capita value transferred to Municipalities. Transfers to States continued to be greater than those to Municipalities until 2007, followed by an inconsistent pattern of growth/drop which ended in 2014 with a lower value than that transferred in the beginning of the period ( $R$ \$ 31.91).It should be noted that in 2012 the per capita value transferred to States had a great increase as a consequence of demands included in the PAR for the period between 2011 and 2014. Therefore, the data 
shows that, in general, there was a greater volume of transfers to Municipalities than to States.

The impact on the new policy on the transfer of federal resources to the regions with the lowest educational indicators was demonstrated by the evolution in the per capita values transferred to different regions during the period under investigation (20042014). In general, all regions experienced an increase in the per capita values transferred, although at different rates (see Figure 2).

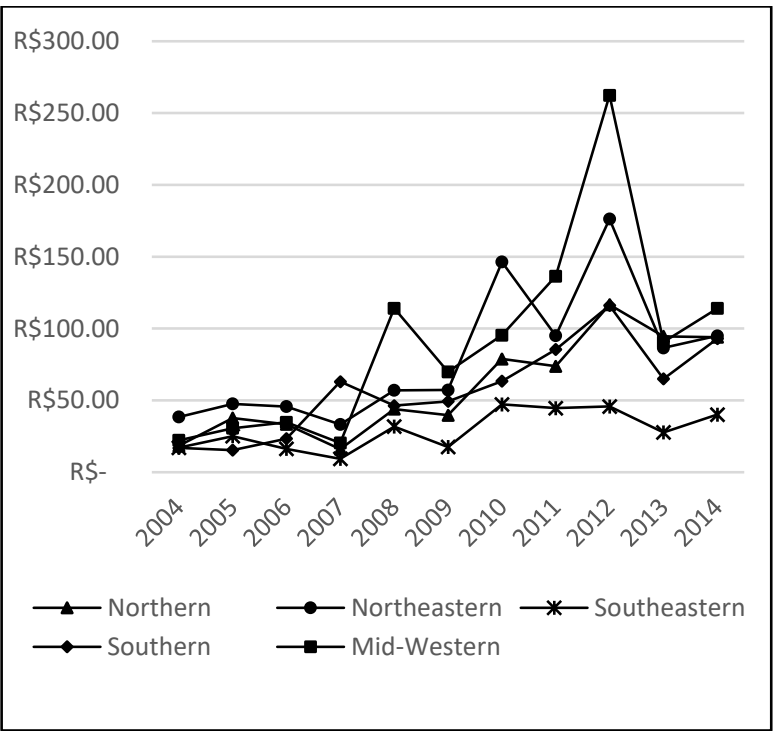

Figure 2. Evolution of the per capita values transferred to all regions of the country, 2004-2014

The figure also demonstrates that as the per capita value increased over time so did the differences among regions. In 2004, the lowest per capita value was transferred to the Southern region $(\mathrm{R} \$ 16.93)$ and the highest was transferred to the Northeastern region ( $\mathrm{R} \$$ 38.45), a difference of $127 \%$. From 2007 onwards, the differences between the lowest and the highest values transferred to different regions consistently increased so that, in 2012, the per capita value transferred to the Northeastern region ( $\mathrm{R} \$ 176.25)$ was $285 \%$ higher than that transferred to the Southern region $(\mathrm{R} \$ 45.76)$.

It is worth noting that transfers to the Southern region had the lowest rates of change over the period. On the other hand, from 2007 onwards, the Northeastern and Mid-Western regions received the highest level of resource transfers. However, the pattern of transfers changes significantly when analyzing the data by region and by type of government. That is, Figures 3 and 4 show that differences among regions are determined more by transfers to the State governments rather than to the Municipal ones.

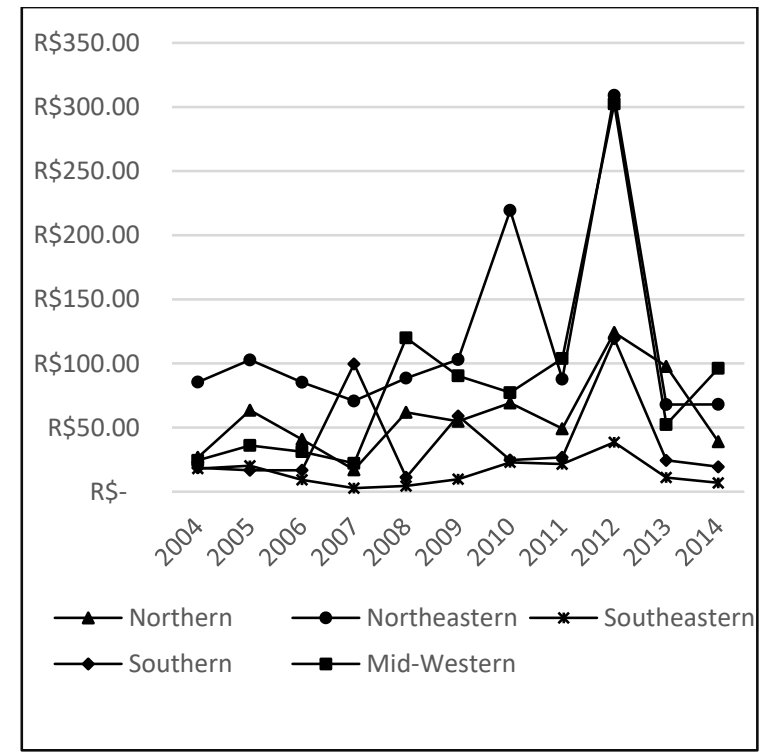

Figure 3. Evolution of the per capita values transferred to state governments in each region (2004-2014)

Figure 3 shows that between 2004 and 2014 all regions experienced increases in the value of per capita transfers to State governments, with the exception of the Southeastern region. Among the regions that experienced increases, State governments in the Northeastern region received the highest value of such transfers, an average value of $\mathrm{R} \$ 117.14$. The next highest increase was observed for the Mid-Western region, with an average value of $\mathrm{R} \$ 86.95$ transferred to State governments. The Southeastern region had the lowest level of per capita transfers throughout the period under investigation, with an average value of $\mathrm{R} \$ 15.05$.

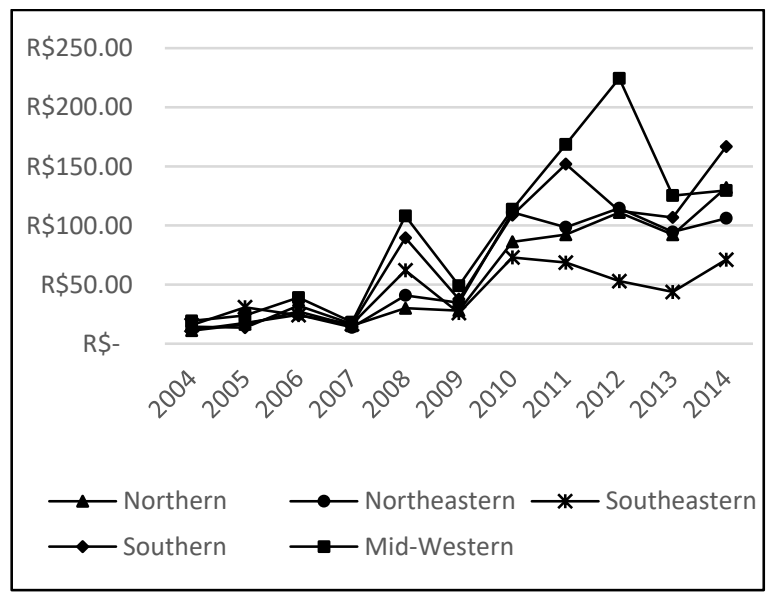

Figure 4. Evolution of the per capita values transferred to municipal governments in each region (2004-2014)

The ranking of regions changes considerably when analyzing transfers to Municipal governments. Up to 
2007, the value of per capita transferred to the Municipal governments presented a small difference between the regions (see Figure 4). Greater differences of such values only occurred in 2008 and from 2010 onwards.

Concerning the position of the regions, the Southern region which ranked in the fourth position in transfers to State governments, now, in transfers to Municipal governments, ranks most of the time in the second position, with an average transfer value of $\mathrm{R} \$ 77.35$, which is lower only than the value of the Mid-Western region ( $\mathrm{R} \$ 92.66)$. At the same time, the Northeastern region now ranks alternatively in the third and fourth positions, even though the region experienced a significant increase $(823 \%)$ in the per capita values transferred to its Municipal governments.

Greatest increases, however, were observed for the Northern and Southern regions $(1,106 \%$ and $1,058.7 \%$, respectively). It should be noted that increases in the Northern and Northeastern regions resulted from the fact that, of the 1,242 municipalities prioritized for assistance transfers, $83 \%$ were located in the Northern and Northeastern region. In addition, the new parameters for calculating the per capita value of the programs have an effect on these regions. However, this is not the case in the Southern region.

These results indicate that there is an association between regional inequalities and level of government receiving transfers. Evidence of such association relates to the finding that State governments in the Northeastern region received more resources than the State governments of any other region, while the Municipal governments in the Northeastern region, even though they were prioritized for transfers, did not receive the highest per capita value transferred. Nevertheless, such prioritization did raise appreciably the per capita value transferred for these Municipalities (an increase of $823 \%$ ) while the increase in transfers to State governments increased $79.6 \%$.

It can be concluded, therefore, that the mechanisms employed by the Federal government to increase support to regions with the lowest educational indicators did improve the situation of the Northeastern municipalities, it was not sufficient to overcome the depth and complexity of the inequalities present in this region.

As demonstrated in Table 1, of the 20 municipalities that received the highest volume of per capita value transfers, none are in the Northeast, one is in the North, four are in the Mid-West, four are in the Southeast, and 11 are in the South. In addition, it should be noted that, with the exception of four Municipalities, all other had IDEBs above the national average.
Table 1. Municipalities receiving highest per capita transfers, 2004-2014

\begin{tabular}{|c|c|c|c|c|}
\hline Region & State & Municipality & $\begin{array}{l}\text { Per } \\
\text { Capita } \\
\text { Value }\end{array}$ & IDEB \\
\hline Southern & $\mathrm{RS}$ & Dois Lajeados & $1,450.46$ & 6.8 \\
\hline Southeastern & SP & Nova Castilho & $1,102.80$ & 5.3 \\
\hline Southern & RS & $\begin{array}{l}\text { Salvador Das } \\
\text { Missões }\end{array}$ & $1,070.08$ & 7.2 \\
\hline Southern & $\mathrm{SC}$ & Ouro Verde & $1,013.67$ & 5.9 \\
\hline Southern & RS & Braga & 920.25 & 5.1 \\
\hline Mid-Western & GO & Davinópolis & 919.27 & 6.0 \\
\hline Southern & RS & $\begin{array}{l}\text { Benjamin } \\
\text { Constant do Sul }\end{array}$ & 908.91 & 4.1 \\
\hline Southern & RS & Montauri & 902.73 & 7.3 \\
\hline Mid-Western & MS & Vicentina & 838.14 & 5.6 \\
\hline Northern & TO & Juarina & 830.67 & 4.7 \\
\hline Mid-Western & GO & Água Limpa & 823.39 & 6.0 \\
\hline Southeastern & SP & $\begin{array}{l}\text { Santa Clara } \\
\text { d'Oeste }\end{array}$ & 821.15 & 6.0 \\
\hline Southeastern & SP & Turmalina & 812.48 & 7.0 \\
\hline Southern & $\mathrm{RS}$ & Tio Hugo & 808.18 & 4.0 \\
\hline Mid-Western & GO & Jesúpolis & 793.83 & 6.0 \\
\hline Southern & RS & $\begin{array}{l}\text { Vista Alegre Do } \\
\text { Prata }\end{array}$ & 783.01 & 8.2 \\
\hline Southeastern & $\mathrm{SC}$ & Coronel Martins & 757.00 & 5.2 \\
\hline Southeastern & SP & Lourdes & 754.57 & 6.3 \\
\hline Southern & $\mathrm{RS}$ & Barra Funda & 753.76 & 4.9 \\
\hline Southern & RS & Colinas & 734.98 & 6.4 \\
\hline
\end{tabular}

Table 2 identifies the 20 Municipalities in the Northeastern region that received the highest per capita values. The data demonstrates that Municipalities that received the highest per capita values were those with relatively low IDEBs. It should be noted that the highest value received by a Municipality in the Northeastern region (Mato Grosso, PB) was about half of the value received by the Municipality that received the highest value in the country (DoisLajeados, RS, see Table 1).

Table 2. Municipalities in the Northeastern region receiving the highest per capita value transfers, 20042014

\begin{tabular}{l|l|c|c}
\hline State & Municipality & $\begin{array}{l}\text { Per Capita } \\
\text { Value }\end{array}$ & IDEB \\
\hline PB & Mato Grosso & 737.98 & 3.5 \\
PI & Vila Nova do Piauí & 603.39 & 5.5 \\
PB & Serra da Raiz & 570.27 & 2.7 \\
PB & Alcantil & 568.07 & 2.9 \\
MA & Colinas & 566.33 & 3.2
\end{tabular}




\begin{tabular}{l|l|c|c} 
& Olho d'Água do & 499.56 & 2.8 \\
RN & Borges & 497.71 & 2.8 \\
PB & Gurjão & 494.61 & -- \\
RN & Lucrécia & 482.17 & 3.4 \\
BA & Cordeiros & 479.49 & 2.1 \\
RN & Riacho da Cruz & 475.76 & -- \\
RN & Almino Afonso & 471.06 & -- \\
PB & Zabelê & 468.80 & 3.8 \\
SE & São Francisco & 466.80 & 3.0 \\
RN & Venha ver & 462.83 & 2.8 \\
PE & Moreilândia & 453.43 & 3.8 \\
RN & Doutor Severiano & 443.05 & -- \\
RN & Major Sales & 429.18 & 1.9 \\
RN & Fernando Pedroza & 418.67 & 3.3 \\
PI & Bela Vista do Piauí & 413.52 & 4.5 \\
RN & São João do Sabugi & \\
\hline
\end{tabular}

It should also be pointed out that of the 20 Municipalities in the Northeastern region that received the highest per capita values only seven were originally regarded as priority for receiving federal support. This evidence suggests that even though there were significant increases in the per capita values transferred to Northeastern Municipalities, the prioritization originally developed may not have taken into consideration all factors contributing to the inequalities amongst regions. Therefore, it appears that federal support policies ought to consider additional criteria that could have the potential to alter existing inequalities.

Some hypotheses can be advanced to explain the favorable position for receiving federal funding of the Municipalities in the Mid-Western and Southern regions, and the unfavorable position for such funding of those in the Northern and Northeastern regions. The receipt of the highest per capita values by the Municipalities of the Mid-Western and Southern regions may have been due to the fact that, one, these regions already had very high values in comparison to other regions of the country; two, they had a better administrative structure that enabled them to better access Federal Government assistance resources, and three, and most importantly, these regions had a greater degree of political influence because some of the Federal decision makers came from these regions and therefore favored them.

On the other hand, the Municipalities of the Northern and Northeastern regions have low administrative capacity for the execution of policies, so that even if they are prioritized, they cannot maintain the receipt of resources. It should be noted that the maintenance of the transfer of Federal Government assistance resources depends on recipients, first, to maintain their fiscal situation on target (without default) and, second, to demonstrate having executed successfully the planned stages of programs. If any of these conditions are not met remittances are terminated. Consequently, because per capita values are calculated on the basis of transfers actually realized, values not received end up lowering the actual per capita value for either the State or Municipalities.

As a consequence, capabilities of Municipalities all over the country explain the findings that, of the group of twenty Municipalities that received most of the per capita transfers from 2004 to 2014, none is located in the Northeast, one is in the North, four are in the Midwest, four in the Southeast and 11 in the South. Therefore, it can be concluded that the Federal Government assistance policy has improved the situation of the Municipalities in the Northern and Northeast regions, but not sufficiently to overcome the challenges present in these regions.

\section{Tensions between the Induction of the Federal Government and the Autonomy of the Federated Units}

The literature offers the foundation for analysis of such relationships in federated systems. Arretche [6,7] and Tsebelis [8] points out that, in federated systems, the central government always has, to a greater or lesser extent, mechanisms to influence the agenda of subnational governments. Arretche [6] suggests that such influence can occur both through federal regulation and the design of policies under which the central government has decision-making authority. Tsebelis [8] argues that, additionally, central governments can control the arena of negotiations by designing policy procedures aimed at reducing the number of veto players, controlling the dimensions of negotiations, and, thus, influencing the agenda of sub-national governments.

These two perspectives were used to analyze, one, the regulations of the Brazilian Federal Government technical and financial assistance policy and, two, the issue of the autonomy of the federated units. Findings revealed that, from 2007 onwards, the Federal Government has increased its influence on the educational agenda of sub-national governments through three main mechanisms.

The first mechanism involved changing the design of the technical and financial assistance policies. Arretche [6] advances that, the capacity of the Federal Government to coordinate actions between spheres of government is directly affected by the way the federative relations are structured in the design of 
particular policies. Findings from my investigation corroborate this argument. The new design of the Federal Government technical and financial assistance policy incorporated a set of four strategic measures that allowed greater influence on the educational agenda of the sub-national governments:

1) Designing national programs that included diverse areas of content and resource transfer mechanisms.

2) Regulating the assistance beyond its technical and bureaucratic aspects by incorporating guidelines and political-pedagogical arrangements. This approach transformed programs from simple mechanisms of resource transfer to promoters of basic education policies.

3) Orienting the planning of the State and Municipal education systems (through the Articulated Actions Plan, PAR) and the monitoring of such plans through the Basic Education Development Index, IDEB.

4) Prioritizing groups of Municipalities as beneficiaries of specific policies elaborated by the Ministry of Education.

These strategies have increased the capacity of federal coordination of governmental actions because each strategy focuses on a specific level of the educational system, from the most macro (State and Municipality Planning of Education) to the most micro level (formatting actions to be implemented by schools).

The second mechanism used by the Federal Government to increase its influence on the educational agenda of sub-national governments involves three main strategies, all focused on developing approaches for negotiating and mediating policies, and reducing the influence of veto players.

The first strategy relates to legal and voluntary transfers regulated by federal normative acts. Such transfers constitute effective mechanisms for the implementation of educational policies because they restrain players with veto power prevalent in the federative regime. Such strategy corroborates notions proposed by Tsebelis [8] who explains that policy stability decreases when the size of the yolk of each of these actors with veto power increases. (Yolk is a concept defining the scope of action of all actors in a common policy, and can be both an area of congruence and divergence).

Accordingly, when the Federal Government conditions the transfers of assistance resources to the adoption of its own policy, it is able to implement the policies it wants, nullifying the influence of the veto players and therefore enhancing the stability of the policy. The strategy was then to regulate the transfers through the National Fund for Education Development $(F N D E)$, without the participation of any representative of eh the State and Municipalities in the decision- making process. This practice also has implications regarding true democratic principles where State and Municipal institutions would have the right to participate in the decision-making process.

The second strategy involves negotiating directly with Municipal governments, bypassing the influence of State representatives. Evidence shows that the Direct Money in Schools Program (PDDE - Programa Dinheiro Diretona Escola) has been the program that grew the most over the period studied. In this way, the Federal Government has be able to increase the chances that its policy will be implemented as it was designed.

The third strategy focused on reaching consensus amongst key actors regarding the acceptance by the Municipalities of the integrity of federal program. The use of this strategy has been justified by both Arretche $[3,4]$ and Tsebelis [8]. Arretche [3, 4] argues that although the design of the policy is influential on the promotion of acceptance, it is not sufficient because there is always the possibility that certain actors might not agree with the proposed design. In such situations, Tsebelis [8] suggests that consensus can be achieved more effectively by influencing a key institutional actor who could persuade other veto players to adhere to the proposed policy.

In our investigation, evidence showed that the Federal Government mobilized political resources to achieve the desired consensus among the two key actors in the educational system, i.e., the National Union of Municipal Education Managers (UNDIME- União Nacionaldos Dirigentes Muncipais de Educação) and the National Union of Municipal Councils of Education (UNCME - União Nacional dos Conselheiros Municipais de Educação). These entities, as representatives of managers of municipal education systems, have a great power of convincing and aligning the discourse of their bases. The consensus was obtained both through previous dialogues with both these entities, and through the transfer of free regulatory resources to them, which in the period studied summed up to $\mathrm{R} \$ 27.9$ million.

So, in general, our investigation identified the existence of trends in the relationship between the Federal, and the State and Municipalities' governments in Brazil, all leading to a model that can be called "induced and dependent cooperation" amongst Federal, State and Municipal governments. The observed trends include (a) limited instances of shared decision making, (b) the use by the Federal Government of diverse mechanisms for inducing adoption of policies, (c) limited capabilities of the Municipalities to exercise its autonomy, and (d) the existence of limited capabilities in the Municipalities of the Northern and Northeastern regions of Brazil to administer financial resources and implement policies. 


\section{Conclusions}

Our investigation demonstrated that the Federal Government assistance policy was an important area for the study of federative tensions between the Federal, and the State and Municipal Governments. The results show that from of 2004 onward, a new assistance policy of the Federal Government took place in Brazil. This policy was based on national assistance programs with their actions formatted by Federal Government, without effective participation of State and Municipal governments. The findings our investigation evidenced a tension in the Federal Government assistance policy. This tension involves on the one hand, the power of the Federal Government to elaborate educational policies to be implemented in the States and Municipalities, and, on the other hand, the limited capability of the States and Municipal governments to exercise their autonomy to implement such policies, mainly the Municipalities located in the Northern and Northeastern regions of the country.

The Federal Government assistance policy originally aimed to promoting equity among the regions of the country. However, this did not happen during the period under investigation. Reasons for barriers included the territorial inequalities in Brazil related to limited administrative capacity, the existence of clientelist practices, the low degree of the prevalent democratic culture and low capabilities in project management, specifically of the Municipalities. These barriers are the principal limitation for the allocation, and the efficient and effective utilization of available resources.

According to Elazar [2], the interdependence that characterizes the relationships among all levels of federations requires the employ of processes that promote the sharing of decision making about public policies. And, even though the Constitution establishes the basic directives for the education policies, the detailing of related policies depends on largely the dynamics of intergovernmental relations, the configuration of political institutions, the design of public policies and the administrative conditions of the federated units. Evidence of this inter-dependence was observed in the study of Federal assistance to subnational federated units for the provision of basic education in Brazil between 2004 and 2014.

\section{References}

[1] Cavalcanti, C. R. Tensões federativas no financiamento da educação básica: equidade, qualidade e coordenação federativa na assistência técnica e financeira da União. Tese [Doutorado em Educação]. Universidade Federal de Minas Gerais. Belo Horizonte, 2016.

[2] Elazar, D. J. Exploring federalism. Alabama, The University of Alabama Press, 1991.
[3] Bardin, L. L'analyse de contenu. Paris: PressesUniversitairies de France, 1977.

[4] Burgess, M. Comparative federalism: theory and practice. New York: Routledge, 2006.

[5] Watts, R. Comparing federal systems. Montreal: McGillQueen's University Press, 2008.

[6] Arretche, M.Democracia, federalismo e centralização. Rio de Janeiro: Editora FGV; Editora Fiocruz, 2012.

[7] M. Arretche, Federalismo e políticas sociais no Brasil: problemas de coordenação e autonomia. São Paulo em perspectiva,São Paulo, 2004, v.18, n. 2, p.17-26.

[8] G. Tsebelis, Decision making in political systems: veto players in presidentialism, parlamentarism, multicameralism and multipartyism. British Journal of Political Science.Londres, 1995, v. 25, n.3, p.289-325, 